\title{
Impact of a free public transportation service for rural households
}

\section{Dampak layanan angkutan gratis untuk rumah tangga pedesaan}

\author{
Slamet Rosyadi ${ }^{*}$, Shadu S.Wijaya ${ }^{2}$, M. Husnul Maab ${ }^{2}$, Zaula Rizqi Atika ${ }^{2}$, \& Chamid Sutikno \\ ${ }^{1}$ Department of Public Administration, Faculty of Social and Political Sciences, \\ Universitas Jenderal Soedirman \\ ${ }^{2}$ Study Program of Public Administration, Universitas Nahdlatul Ulama Purwokerto \\ Address: ${ }^{1}$ Jalan Kampus 12, Banyumas, Central Java 53122 \\ ${ }^{2}$ Jalan Sultan Agung 42, Banyumas, Central Java 53145 \\ E-mail: slamet.rosyadi@unsoed.ac.id
}

\begin{abstract}
The transportation service subsidy is intended to ease the burden of students from low-income families by helping with their need for mobility. The local government provides a transportation service expenditure budget annually to pay for the transportation services they require. Theoretically, the subsidy benefits the poor, although a study on the evaluation of the transportation service subsidy program is still needed to ascertain whether the program beneficiaries benefit from the program. This study used a survey method, and it deepened by the in-depth interviews conducted with 98 respondents. It used to obtain supporting information to pair with the survey results. The critical findings from this study are that the subsidy program has increased the rate of savings in terms of transportation service spending, and it has also reduced the burden of food expenditure among the poor. Better access to education services among the program recipient students reduced traffic congestion, and the enthusiasm for learning within low-income family students are also benefits. Another benefit is that the public transport drivers involved in the program get sustainable income certainty. The income of the recipient community groups has increased moderately compared to the non-recipient groups. However, saving on transportation spending does not contribute significantly to the burden of food expenditure for low-income families. The reason for this is that the free transportation subsidies received by the poor are minimal in terms of the frequency of coupon use. This study concludes that free transport subsidies in the short term can alleviate the burden on the poor, and in the long run, they can improve the welfare of the poor.
\end{abstract}

Keywords: transportation service subsidy; poor people; rural household

\begin{abstract}
Abstrak
Subsidi layanan transportasi dimaksudkan untuk meringankan beban masyarakat dan pelajar dari keluarga miskin dalam melakukan mobilitas. Pemerintah daerah menyediakan anggaran belanja layanan transportasi setiap tahunnya untuk membayar layanan transportasi tersebut. Meskipun secara teoritik subsidi tersebut menguntungkan kelompok miskin, kajian evaluasi program subsidi pelayanan transportasi diperlukan untuk memastikan apakah mereka diuntungkan oleh program tersebut. Penelitian ini menggunakan metode survey dan diperdalam dengan wawancara mendalam pada 98 responden untuk mendapatkan informasi pendukung terhadap hasil survey. Temuan-temuan penting dari studi ini adalah program subsidi telah meningkatkan penghematan belanja layanan transportasi dan penurunan beban belanja pangan di kalangan kelompok miskin, akses pelayanan pendidikan di kalangan siswa penerima program, pengurangan kemacetan lalu lintas, dan semangat belajar siswa keluarga miskin. Manfaat lainnya adalah para sopir angkutan umum yang terlibat dalam program mendapatkan kepastian pendapatan secara berkelanjutan. Pendapatan kelompok masyarakat penerima program meningkat secara moderat dibandingkan kelompok bukan penerima. Namun demikian, penghematan belanja transportasi tidak memberikan kontribusi yang besar terhadap beban belanja pangan keluarga miskin. Alasannya adalah subsidi angkutan gratis yang diterima oleh kelompok miskin sangat terbatas dari segi frekuensi penggunaan kupon. Studi ini menyimpulkan bahwa subsidi angkutan gratis dalam jangka pendek dapat meringankan beban belanja kelompok miskin dan dalam jangka panjang dapat meningkatkan kesejahteraan masyarakat miskin.
\end{abstract}

Kata kunci: subsidi layanan transportasi; masyarakat miskin; rumah tangga pedesaan

\section{Introduction}

One essential factor involved in supporting poverty reduction strategies is targeted and welldeveloped poverty alleviation programs. Some examples of impactful poverty reduction programs include social assistance programs (Putra, Purnamadewi, \& Sahara 2015) and national community empowerment programs (Madjid, Masinambow, \& Wauran 2015). As a result, the number of poor 
people in Indonesia over the past ten years has continuously declined. In 2019, the Indonesian population who live in poverty will be down to 26.58 million people or $9.41 \%$. This number has decreased from the previous decade, where there was a total of 35.3 million people identified as poor or $14.15 \%$ in 2016 (Badan Pusat Statistik 2019).

There is a close relationship between poverty, rural areas, and transportation access (Lucas et al. 2016, Velaga et al. 2012, Dorosh et al. 2012, Bryceson et al. 2008, Kidder 2006, \& Porter 2002). The terrain of the rural areas is because they are commonly located in remote places, forcing the village community to spend seven times more on transportation compared to the urban community. It is in order to access public services and the market (Litman 2017). In Indonesia, the cost of transportation considered to be high due to the inconvenient modes of transportation, the lack of safety, and the unaffordable price for particular groups with a low purchasing power (Aminah 2006). The absence of transportation services that cover rural areas further exacerbates the poverty level. The Central Bureau of Statistics or Badan Pusat Statistik (BPS) reported that only $7.02 \%$ of the urban population is poor, whereas the number of poor people in villages is double that number $13.02 \%$ (Kompas 2018).

Kebumen Regency is one of the regions in Central Java Province with a high poverty rate. The number of poor people in Kebumen is ranked fourth below Brebes, Banyumas, and Cilacap. In 2017, the poor population of Kebumen totaled 233.450 .000 people or around $19.60 \%$ of the total population. This condition far better compared to the surrounding regencies such as Banyumas, with 283.250 .000 poor people and Cilacap with a poor population amounting to 238.320.000 (Badan Pusat Statistik 2017). One strategy to overcome poverty determined by Kebumen Government is improving the public transportation system by providing free public transportation (Angkutan gratis or Angtis) to the poor population. The Kebumen Regent inaugurated the free public transportation program in October 2016 for three regions, including Rowokele District, Karanggayam District, and Sempor District. A year later, the outreach of the program was expanded to 24 sub-districts. The free public transportation program in Kebumen Regency, as stated in Regent Regulation Number 53 the Year 2016 and Regent Regulation Number 13 the Year 2017 Chapter II Article 2, aims to reduce the regional poverty rates.

The free public transportation program was aimed at poor people and students by facilitating them with a coupon to pay for their public transportation fees. The transport provider will exchange the collected coupons from the passengers for a sum of money according to the rate set by Kebumen Transportation Agency. This program has changed the transaction behavior that is initially between the passengers and the transportation provider, shifting it to a more systematic pattern. Since the launching of the program, the public expectation is that it will benefit the underprivileged. However, several shortfalls have arisen along with the implementation of the free public transportation program, such as the limited regarding the number of coupons (Suara Merdeka 2017) and the length of the coupon payments received by the public transport service providers (Kebumen Ekspres 2017). Although the subsidies intended to benefit the poor, an evaluation of the program is required to ascertain the real benefit received by the targeted group through the program. The research questions proposed from the evaluation and study of the free public transportation program in Kebumen are how is the implementation of the free public transportation program in Kebumen? And What are the impacts and benefits received by the poor in Kebumen through the program?

\section{Research Method}

This research applied a policy evaluation method to compare an event, activity, and product with the standards of a predetermined program. This study employed a survey method for the recipients of the Hope Family Program or Program Keluarga Harapan (PKH) as the free public transportation target group. A survey was also conducted on rural transport drivers involved in free public transportation in order to assess the benefits of the program for them. The research locus was in Kebumen Regency. This study conducted sampling at the location of the free transportation program carried out in 20162017, which included 24 Districts in Kebumen. Theoretically, the policy includes initial, intermediate, and long-term outcomes. The targets in this study were divided into two groups is respondents and informants. The respondents in this study consisted of the target group and the control group. 
Finsterbusch and Motz (1980) stated that a target group is a group of individuals who are the policy object, who have a distinctive character and who will be intervened for by the government in terms of specific policies. The comparison group is a group of individuals outside of the target group with the same character as the target group who are not intervened with by the same policy or other policies. There are four types of evaluation research designs, including a single program after only, single program before-after, comparative after only, and comparative before after (Wibawa, Prabuningrat \& Pramusinto 1994). The comparative before-after type was considered to be the most suitable type of policy evaluation design here. It is not only able to measure the alteration level before and after each group by identifying the conditions of the target group. This method can also ensure that the results and impact of the policy are the outcomes of the policy performance.

The main target groups in this study include beneficiaries of the free public transportation program, namely the poor community and students in Kebumen Regency. The comparison group (control group) in this study includes people who have the potential to receive the program benefits but who do not use it in Kebumen Regency. To support the results of the survey, this research explores the qualitative data such as opinions and experiences in order to explore the process of implementing the free public transportation service program. In-depth interviews conducted with purposively-chosen informants. The informants in this study were people with adequate knowledge about the implementation of free transportation, including people who had been appointed or given responsibility for managing free transportation in their area. They were the implementers of the free transportation program at the sub-district level. The informants in this study consisted of 1) The Head of Transportation from the Kebumen District Transportation Agency, 2) The Head of Social Welfare in Ambal District, 3) The Coordinator at the Buluspesantren District Level, 4) the PKH assistant of Mirit, Karanggayam, and Rowokele Districts, 5) Gondanglegi Village Apparatus, and 6) Transportation Drivers in Karanggayam, Rowokele, and Ambal.

The population in this study consisted of the objects or subjects in the area who met specific requirements related to free public transportation services. They were the beneficiaries of the free public transportation program in Kebumen Regency. The size of the study population was 3.885 people, and the sample size was determined using the Slovin's Method at a 10\% error rate, resulting in 98 respondents. After acquiring the sample, the next thing to consider was the sampling technique. Sampling was based on the research locus. One sample was obtained from each sub-district for the community samples. As for the students, each sub-district took three or four people. By using a list of PKH recipients as a sampling frame, sampling performed through a simple random sampling system (Table 1).

The control group sample was determined by the students and family members of $P K H$ recipients who did not use free public transportation due to the available routes not being suitable to meet their needs. The sample size from the control group was the same as the target group to obtain an equal comparison. This study employed quantitative methods using the following data analysis techniques: 1) Descriptive Statistics, this method was used to analyze the process of the free public transportation service program implementation and 2) Linear Regression, this method was used to examine the hypothesis that states that there is a positive and significant effect from the program on the transportation expenses of low-income families. Formula 1 is the linear regression formula according to Kurniawan \& Yuniarto (2017).

Lester and Stewart (in Winarno 2008:166) suggest that a policy evaluation can mainly be divided into two different tasks. The first task is to determine the consequences of a policy by describing its impact. The second task is to assess the success or failure of a policy based on predetermined standards or criteria. Policy evaluation is a method used to measure and assess the stages of policy implementation related to the outcome and impact of a particular policy or program implementation, thus determining the steps that can be taken in the future.

The leading indicators of a policy evaluation are the output indicators and outcome indicators. Output indicators used to determine the direct consequences perceived by the target group as a result of the realization of the activities, distribution, or subsidies. This research intended to evaluate the 
distributive policy that aims to help disadvantaged communities through free services concerning material instruments. According to Purwanto and Sulistyastuti (2015:106), the aspects relating to the evaluation of the program's policies include the following: 1) Accessibility used to find out the method of a target group to access the program or service provided, 2) Coverage used to assess the level of the target group who received the services, 3) Frequency used to measure how often the target group can receive the services as promised in the program, 4) Bias used to assess whether the services provided reach the targeted group or if it benefits a non-eligible group, 5) Accuracy of service used to assess whether the services provided by the program are timely or not, and 6) Accountability used to assess whether the actions of the program implementers when delivering the policy to the target group can be accounted for or not. In addition, in this study, we also focus on the program outcome indicators. According to Purwanto and Sulistyastuti (2015), there are several aspects involved in measuring outcomes: 1) Initial outcomes, 2) Intermediate outcomes, and 3) Long-Term outcomes (Table 2).

Table 1.

Research Population and Sample

\begin{tabular}{|c|c|c|c|c|c|}
\hline \multirow{3}{*}{$\begin{array}{l}\text { Locus } \\
\text { (regency) }\end{array}$} & \multirow{3}{*}{ Population } & \multicolumn{4}{|c|}{ Type of sample } \\
\hline & & \multicolumn{3}{|c|}{ Target group } & \multirow{2}{*}{$\begin{array}{l}\text { Control } \\
\text { group }\end{array}$} \\
\hline & & Student & People & Total & \\
\hline Ayah & 188 & 3 & 1 & 4 & \multirow{24}{*}{98} \\
\hline Ambal & 270 & 4 & 1 & 5 & \\
\hline Rowokele & 189 & 3 & 1 & 4 & \\
\hline Karangqayam & 241 & 3 & 1 & 4 & \\
\hline Karangsambung & 242 & 4 & 1 & 5 & \\
\hline Alian & 212 & 3 & 1 & 4 & \\
\hline Padureso & 199 & 3 & 1 & 4 & \\
\hline Mirit & 233 & 3 & 1 & 4 & \\
\hline Sadang & 134 & 3 & 1 & 4 & \\
\hline Klirong & 110 & 3 & 1 & 4 & \\
\hline Pejagoan & 228 & 3 & 1 & 4 & \\
\hline Petanahan & 174 & 3 & 1 & 4 & \\
\hline Buluspesantren & 120 & 3 & 1 & 4 & \\
\hline Puring & 123 & 3 & 1 & 4 & \\
\hline Buayan & 192 & 3 & 1 & 4 & \\
\hline Bonorowo & 70 & 3 & 1 & 4 & \\
\hline Sempor & 82 & 3 & 1 & 4 & \\
\hline Prembun & 195 & 3 & 1 & 4 & \\
\hline Kutowinangun & 159 & 3 & 1 & 4 & \\
\hline Kebumen & 213 & 3 & 1 & 4 & \\
\hline Karanganyar & 36 & 3 & 1 & 4 & \\
\hline Sruweng & 30 & 3 & 1 & 4 & \\
\hline Kuwarasan & 120 & 3 & 1 & 4 & \\
\hline Gombong & 125 & 3 & 1 & 4 & \\
\hline Total & 3885 & 74 & 24 & 98 & 98 \\
\hline
\end{tabular}

The leading indicators of a policy evaluation are the output indicators and outcome indicators. Output indicators used to determine the direct consequences perceived by the target group as a result of the realization of the activities, distribution, or subsidies. This research intended to evaluate the distributive policy that aims to help disadvantaged communities through free services concerning material instruments. According to Purwanto and Sulistyastuti (2015: 106), the aspects relating to the evaluation of the program's policies include the following: 1) Accessibility used to find out the method of a target group to access the program or service provided, 2) Coverage used to assess the level of the target group who received the services, 3) Frequency used to measure how often the target group can receive the services as promised in the program, 4) Bias used to assess whether the services provided reach the targeted group or if it benefits a non-eligible group, 5) Accuracy of service used to assess whether the services provided by the program are timely or not, and 6) Accountability used to assess whether the actions of the program implementers when delivering the policy to the target group can be accounted for or not. In addition, in this study, we also focus on the program outcome indicators. According to Purwanto and Sulistyastuti (2015), there are several aspects involved in measuring outcomes: 1) Initial outcomes, 2) Intermediate outcomes, and 3) Long-Term outcomes (Table 2). 
Formula 1.

Linear regression formula (Kurniawan \& Yuniarto 2017)

$$
\begin{gathered}
Y=a+b X \\
b=\frac{n \sum X Y-\Sigma X \Sigma Y}{n \Sigma X^{2}-(\Sigma X)^{2}} \\
a=\frac{\sum Y-b \Sigma Y}{n}
\end{gathered}
$$

Note:

$\mathrm{n}=$ Sample

$\mathrm{a}=$ Constant value

$b=$ Regression coefficient

\begin{tabular}{|c|c|c|}
\hline Focus & Aspect & Sub-aspect \\
\hline \multirow{9}{*}{$\begin{array}{l}\text { Free public } \\
\text { transportation program } \\
\text { implementation in } \\
\text { Kebumen (output) }\end{array}$} & & $\begin{array}{l}\text { Equality of the program recipients in } \\
\text { obtaining coupons }\end{array}$ \\
\hline & Accessibility & Program accessibility \\
\hline & & $\begin{array}{l}\text { Ease of communication with the program } \\
\text { holder }\end{array}$ \\
\hline & & $\begin{array}{l}\text { Comparison between the targeted } \\
\text { groups: the total of coupon recipients }\end{array}$ \\
\hline & Coverage & $\begin{array}{l}\text { Comparison between the drivers and } \\
\text { the number of coupons exchanged by } \\
\text { drivers }\end{array}$ \\
\hline & Frequency & $\begin{array}{l}\text { The frequency of people using the free } \\
\text { public transportation service }\end{array}$ \\
\hline & Bias & Target accuracy \\
\hline & Accuracy of service & Service delivery time \\
\hline & Accountability & Program report \\
\hline \multirow{3}{*}{$\begin{array}{l}\text { Transformation and } \\
\text { benefits/advantages } \\
\text { gained by the targeted } \\
\text { group (outcomes) }\end{array}$} & Initial Outcomes & Saving expenditure \\
\hline & Intermediate Outcomes & Expenditure distribution \\
\hline & Long-Term Outcomes & $\begin{array}{l}\text { Long-term impact after free public } \\
\text { transportation program implementation }\end{array}$ \\
\hline
\end{tabular}

$X=$ Dummy Variable (if participated $=1$, if not $=0$ )

$Y=$ Savings on transportation expenses

Table 2.

Operational Definition Matrix

Source: Purwanto and Sulistyastuti (2015)

\section{Results and Discussion}

The process of implementing the free public transportation program

To evaluate the free public transportation implementation process, indicators are needed to measure the implementation performance. Referring to Purwanto and Sulistyastuti (2015), program implementation performance includes six indicators: accessibility, scope, frequency, bias, accuracy, and accountability. Measuring the implementation performance and evaluating the program implementation process is important because the program implementation process is often progressed outside of the predetermined target (Brinkerhoff \& Crosby 2002). In other words, there are potential gaps between the objectives and outputs. 


\section{Accessibility}

A good program is an accessible and highly utilized program according to the community. The ease of the program's conduction can be supported by several aspects, such as how it conforms to address the needs that have arisen, infrastructure affordability, and the ease of communication with the program implementers. The distances from the residents' houses to public transportation stops are diverse. Table 3 illustrates the distances traveled by the community to access free public transportation. Based on the Table 3, the furthest distance is $1-2 \mathrm{Km}$, while the average distance for people accessing transportation is $3.100 \mathrm{~m}$. The considerable distance illustrates that despite the availability of the program, rural communities still need more of an effort to reach the nearest stops. The availability of the fleet also affects the level of program accessibility. The following is a community evaluation of the level of ease when accessing public transportation.

Table 3.

Distance from home to the nearest free public transportation stop

\begin{tabular}{lcc}
\hline Distance $(\mathbf{m})$ & Amount & \multicolumn{1}{c}{$\%$} \\
\hline $1-999$ & 17 & 17.3 \\
$1000-1999$ & 26 & 26.5 \\
$2000-4999$ & 18 & 18.4 \\
$5000-9999$ & 17 & 17.3 \\
$10000-15000$ & 8 & 8.2 \\
Unknown & 12 & 12.2 \\
\hline Total & $\mathbf{9 8}$ & $\mathbf{1 0 0}$
\end{tabular}

Source: Analysis of the primary data (2018)

Table 4.

Ease of accessing transportation

\begin{tabular}{lcccc}
\hline \multirow{2}{*}{ Answer } & \multicolumn{2}{c}{ Targeted group } & \multicolumn{2}{c}{ Control group } \\
\cline { 2 - 5 } & Amount & \% & Amount & $\%$ \\
\hline Very easy & 20 & 20.4 & 30 & 30.6 \\
Easy & 43 & 43.8 & 40 & 41 \\
Hard & 31 & 31.7 & 25 & 25.3 \\
Very hard & 4 & 4.1 & 3 & 3.1 \\
\hline Total & $\mathbf{9 8}$ & $\mathbf{1 0 0}$ & $\mathbf{9 8}$ & $\mathbf{1 0 0}$ \\
\hline \multicolumn{2}{r}{ Source: } & Analysis of the primary data (2018)
\end{tabular}

Based on Table $4,43.8 \%$ of the target community and $41 \%$ of the control community stated that it was easy to access public transportation in their respective places of residence. Specifically, $20.4 \%$ of the target community and $30.6 \%$ of the control community stated that it was straightforward. Only $4.1 \%$ and $3.1 \%$ of the people stated that it was challenging. The answers were generally related to the insufficient number of fleet buses. The free public transportation program had altered the community behavior to be more enthusiastic when it comes to accessing public transportation, resulting in a surge in the number of passengers. The increase in users was not anticipated by the service providers when adding fleet availability. Concerning the aspect of accessibility, there were no obstacles in the distribution of free public transportation coupons, especially for the coupon distribution officers. This view was obtained based on an interview with IP as the PKH Assistant for Mirit District, as follows:

"How to say it... but in performing our duty, we have to give our best. I don't think there are difficulties when distributing the coupons due to the sufficient amount of the coupons. Also, I do not work alone."

The $P K H$ assistant of Karanggayam district stated a similar answer as follows:

"I work with schools to distribute coupons to poor students. Our access is true to low-income families, so we accompany mothers to get coupons for their children whose schools are 
located far from their house. The availability of the coupons is very adequate, but the amount of the fleet should be increased. Mountainous areas like Karanggayam require more transport fleets than other regions because of the high demand for public transportation in daily use."

Based on the interview, it is apparent that the free public transportation program is accessible for the beneficiary community. The data shows that the free public transportation program is utilized because it is equipped with supporting facilities and suitable infrastructures, such as being at an accessible distance to reach free public transportation, good fleet availability and access to officers. However, there are a few respondents who still face constraints when accessing the fleet.

\section{Scope}

A program is identified as useful if it covers most of the program's target groups - the higher the number of targets involved, the better the program's performance and level of completion. The free public transportation program targets poor citizens and students. The coverage of the free public transportation program is not only related to the coverage of the free public transportation service users, but also the coverage of the public transport fleet itself. Is all of the public transportation available able to serve the targeted community, or can only a partial percentage of the public transport available be utilized as tools for free public transportation? The underlying assumption of the program is that the broader the program reaches in terms of transportation service providers, the better the coverage of the program. Based on the field survey, it can be seen that there are still many poor people and students who have not yet received access to the free public transportation program (Table 5).

Table 5.

The poor community not covered by the free public transportation program

\begin{tabular}{lcccc}
\hline \multirow{2}{*}{ Amount } & \multicolumn{2}{c}{ Targeted group } & \multicolumn{2}{c}{ Control group } \\
\cline { 2 - 5 } & Total & \% & Total & $\%$ \\
\hline Very high & 16 & 16.3 & 23 & 23.5 \\
High & 60 & 61.2 & 50 & 51.0 \\
Low & 22 & 22.5 & 25 & 25.5 \\
Non-existent & - & - & - & - \\
\hline Total & $\mathbf{9 8}$ & $\mathbf{1 0 0}$ & $\mathbf{9 8}$ & $\mathbf{1 0 0}$ \\
\hline \multicolumn{2}{r}{ Source: Analysis of the primary data (2018) }
\end{tabular}

Based on Table $5,16.3 \%$ of the target group answered that a very high percentage of the poor community had not been covered by the program, while $61.2 \%$ answered profoundly. It means that those who have received the free public transportation coupons feel that there are still many other residents who have not yet received the coupon while being eligible to receive the program. This data supported by $51 \%$ of the control group, who also stated that there were still many residents who had not yet received access to the program. This signifies the high community expectations of the program. In terms of the program beneficiary coverage, the respondents stated that program delivery has not been optimal. The interviews with RS as The Head of Social Welfare in Ambal District stated the following:

"This is related to the number of transportation routes. The transportation route does not
cover some of the schools. In Ambal, for Sumberjati, Sidoluhur, Pagedangan, and other areas,
there is no transportation to go to SMKN 1 Ambal (Public Vocational Secondary Schools or
Sekolah Menengah Kejuruan Negeri). The residents who need transportation cannot access
free public transportation because there is no fleet on the route. For the areas that have passed
the transportation route, I think that they can serve the community. The number of public
transportation called angkot is adequate enough to serve the needs of the passengers."

Aside from the interview with The Head of Social Welfare, Ambal District, the interview with a $P K H$ companion from Rowokele District, SR, also stated a similar notion as follows:

"The demand for transportation in Rowokele is high. But there are areas located far out from the existing routes. Plus, the plateau area requires transportation to go to other areas. To reach 
the highway through which the transportation runs in some villages is still difficult. But the number of buses in the fleet should be enough."

The interview with Subdistrict Social Welfare Worker or Tenaga Kesejahteraan Sosial Kecamatan (TKSK) of Buluspesanteren, BS, gave the reason why the program beneficiary coverage is not yet complete. According to BS:

"Limited routes cause poor students to use bicycles or motorbikes to go to school despite the long distance between their houses. Many children do not have a driving license yet. The local community has not yet facilitated access to the program."

Based on the statement above, it is apparent that the program does not cover the entire target group in terms of reaching the program beneficiaries. The partial coverage of the free public transportation program is due to the limited amount of free transportation facilities available when it comes to getting to the schools.

\section{Frequency}

Frequency was used to measure how often the target group can obtain the services available according to the program's intended target. Related to the free public transportation program, the frequency will measure the level of community intensity when using public transport. The frequency of the operating hours of public transportation in Kebumen (Table 6).

Table 6.

Kebumen public transportation operating hours

\begin{tabular}{lccccc}
\hline \multirow{2}{*}{ Intensity } & \multicolumn{2}{c}{ Targeted group } & \multicolumn{2}{c}{ Control group } \\
\cline { 2 - 5 } & Total & $\%$ & Total & $\%$ \\
\hline Public transportation is always available & 14 & 14 & 3 & 3 \\
Public transportation is relatively easy to get & 50 & 51 & 36 & 37 \\
Public transportation is hard to get & 30 & 31 & 33 & 34 \\
Public transportation is severely hard to get & 4 & 4 & 26 & 26 \\
\hline Total & $\mathbf{9 8}$ & $\mathbf{1 0 0}$ & $\mathbf{9 8}$ & $\mathbf{1 0 0}$ \\
\hline Source: Analysis of the primary data (2018)
\end{tabular}

Based on Table 6, both the target group and the control group stated that it was easy to get public transportation when needed during their operating hours. It illustrates that, generally, public transportation in Kebumen operates at the right frequency level. However, some informants still found there to be problems in terms of the frequency of the free public transportation program, such as the limited amount of buses in the fleet and several areas that have not yet been covered by free public transportation routes. According to the interview with DS as the TKSK of Bulus Pesantren Regency, he stated that:

"I observe the availability of the fleet. The public-use free public transportation frequently. However, several areas have not yet been covered by the routes."

Aside from TKSK, Karanggayam Regency Supervisor, ES, assessed the frequency of free public transportation as follows:

\footnotetext{
"The number of free public transportation users is high, especially from among high school students. They have to travel a long distance to go to school, and it is impossible for them when using private transportation. Both the students and their parents are highly welcomed in the program, and they use it for their daily needs and to go to school. This program saves a lot of the student's pocket money that the parents provide."
}

The interview illustrates how the free public transportation program recorded good marks for transportation frequency. Many people have utilized free public transportation to accommodate their daily activities. 


\section{Bias}

A good program is a program that implemented according to the plan and target with fair and nondiscriminative values. Bias explains the number of deviations in a program. Having no deviation is the program's goal and target. With this measurement, we can assess whether free public transportation is truly aiming for the poor group and students. The bias will be measured by identifying the service quality in order to observe the possibility of any discrimination being delivering through the program.

Based on Table 7, we can assess that free public transportation generally operates with a high consideration paid to non-discrimination principles. No difference in treatment was found when it came to serving the users. The discriminative answer that we obtained in the data refers to the distribution pattern, which revealed that groups other than the targeted group are still able to access the free public transportation program. The public perception of the accuracy of the free public transportation coupon distribution has been shown in Table 8 .

Table 7.

Non-discriminative principal level in the public transportation program implementation

\begin{tabular}{lllll}
\hline \multirow{2}{*}{ Level } & \multicolumn{2}{c}{ Targeted group } & \multicolumn{2}{c}{ Control group } \\
\cline { 2 - 5 } & Amount & \% & Amount & $\%$ \\
\hline Non-discriminative & 54 & 55 & 57 & 58 \\
Less discriminative & 29 & 30 & 24 & 25 \\
Discriminative & 9 & 9 & 9 & 9 \\
Highly Discriminative & 6 & 6 & 8 & 8 \\
\hline Total & $\mathbf{9 8}$ & $\mathbf{1 0 0}$ & $\mathbf{9 8}$ & $\mathbf{1 0 0}$ \\
\hline
\end{tabular}

Table 8 shows that $43 \%$ of respondents stated that the distribution of the free public transportation coupon is accurate, while $35 \%$ of them answered that the distribution is less accurate. In addition, $45 \%$ of the control group also answered that the distribution was less accurate. Based on the field observations, the free public transportation program, which specifically targets the poor group, is highly associated with a low social status in society. Thus the free public transportation program has become less attractive for the targeted group due to their consideration of the embedded social status. This has caused the accuracy level of the program implementation below. This was stated in an interview with SMW as follows:

"I personally think that the program has reached the target. No students other than the poor group can use free public transportation because we require them to submit their identity to prove that they are identified as being in the poor group. As long as they have proof, we will give them coupons. Even if they do not have the proof letter, but their actual situation is identified as in the poor group, we will give them the letter. The village won't issue the letter unless they are, indeed, poor"

Most of the recipients of the program use coupons every time they need to travel. Others use a coupon occasionally only when they need to go to market or school. The poor rarely use free public transportation because of their low traveling intensity. Based in Table 9 is $15 \%$ make up the group who never use coupons because they are no longer receiving coupons, and they are unwilling to ask for more coupons from the officials. Based on the information we obtained, the bias concerning the free public transportation program delivery approximately reaches $30 \%$. In other words, there are program beneficiaries that have not utilized free public transportation and vice versa. However, this finding is countered by a statement by the Gondang Legi Village Officers of Ambal regency as follows:

"In my opinion, the distribution of coupons is fair to groups that deserve it. The requirements to get on the program are also quite easy. Those who have never used free transportation 
have to collect copies of KIS, KIP, KKS, and SKTM from the village. As long as they have these, it means that they are still a poor family. So, in my opinion, those who consider that this program is used by people who are already capable only do so because some people's perceptions of poverty are not the same."

From the interview, it is apparent that the accuracy of the free public transportation program coupon distribution is high. The program beneficiaries should be equipped with proof that they are from a poor group that is to be able to use free public transportation.

Table 8.

The accuracy of the free public transportation coupon distribution

\begin{tabular}{lllll}
\hline \multirow{2}{*}{ Level } & \multicolumn{2}{c}{ Targeted group } & \multicolumn{2}{c}{ Control group } \\
\cline { 2 - 5 } & Amount & \% & Amount & $\%$ \\
\hline Highly accurate & 18 & 19 & 12 & 12 \\
Accurate & 42 & 43 & 30 & 31 \\
Less accurate & 35 & 35 & 44 & 45 \\
Inaccurate & 3 & 3 & 12 & 12 \\
\hline Total & $\mathbf{9 8}$ & $\mathbf{1 0 0}$ & $\mathbf{9 8}$ & $\mathbf{1 0 0}$ \\
\hline \multicolumn{4}{c}{ Source: } & Analysis of primary data (2018)
\end{tabular}

\section{Delivery}

Delivery is the officials' ability to organize the program according to the initial plan. In this case, the delivery was measured through the perspective of the service users. From the community point of view, as the main users of the program, delivery was measured using the timeliness of the coupon distribution, the accuracy of the coupon, the accuracy of the fleet (feasibility) and the timeliness of its operations.

According to Table 10, the free public transportation program has been delivered appropriately. For the aspect of the time taken for coupon distribution, the community assessed that the program has been run in a timely manner, although there were some who still complained because they had to wait a long time for the coupon distribution. The coupons utilization frequency of each community is different. Some were used up in one week and some were enough for one month. This was not because the coupons were not ready yet but because the community was waiting for the PKH companions during group meetings. Some students could also take coupons at school because the school was also responsible for distributing coupons to targeted students. In terms of fleet accuracy, the community considered that the fleet was operating in a proper condition. The fleet's operating hours are also at a satisfying level.

Table 9.

Coupon utilization frequency

\begin{tabular}{lll}
\hline \multicolumn{1}{c}{ Utilization frequency } & Amount & \multicolumn{1}{c}{$\%$} \\
\hline Very frequently & 39 & 39 \\
Frequently & 26 & 27 \\
Less frequent & 18 & 19 \\
Never use the coupons & 15 & 15 \\
\hline Total & $\mathbf{9 8}$ & $\mathbf{1 0 0}$ \\
\hline \multicolumn{2}{c}{ Source: Analysis of the primary data (2018) }
\end{tabular}

Based on Table 11, it is known that the fleet in Kebumen is feasible to use. Following this, 43 respondents stated that the public transport fleet in their area is feasible. However, there are remaining shortcomings such as short operating hours and/or an imprecise fleet schedule. Related to program accuracy, on the one hand, RS, as The Head of Social Welfare in Ambal District stated the following: 
"Coupon distribution officers have been working their best. They have also worked with various parties to distribute the coupons. In Ambal, for example, the coordinator at the subdistrict level cooperates with all $P K H$ facilitators, several village officials and also with the administrative staff of high schools."

Based on the statement above, it can be seen that the free public transportation program is quite optimal in terms of service accuracy, considering coupon availability, fleet eligibility and the timeliness of free public transportation's operations. Shortcomings are still found in terms of fleet feasibility and the operating hours of the transportation.

Table 10.

Delivery accuracy of the free public transportation program from the community point of view

\begin{tabular}{lllll}
\hline \multirow{2}{*}{\multicolumn{1}{c}{ Delivery aspect }} & \multicolumn{4}{c}{ Accuracy level } \\
\cline { 2 - 5 } & VT & T & LT & NT \\
\hline Coupon distribution timeliness & 5 & 43 & 40 & 10 \\
Coupon availability & 38 & 15 & 25 & 20 \\
Fleet feasibility & 8 & 48 & 40 & 2 \\
Operation timeliness & 4 & 63 & 26 & 5 \\
Coupon distribution timeliness & 5 & 43 & 40 & 10 \\
Coupon availability & 38 & 15 & 25 & 20 \\
\hline
\end{tabular}

Notes:

VT: Very timely

T: Timely

LT: Less timely

NT: Not-timely; after the proper time

Source: Analysis of the primary data (2018)

\section{Accountability}

Accountability is the principle that determines that each activity and the final results of the program are accountable to the community as the program beneficiaries. The manifestation of the accountability aspect in the free public transportation program is that no fees are needed for people to use the service. Based on Table 12, the majority of the target group people (95\%) answered that they did not pay any fees to get a coupon. Thus the free public transportation program was truly utilized by the community for free. As for the control group, some did not know anything about the free public transportation program. Based on an interview, no report has been found that specifically discusses the performance and budget of the free public transportation program. An interview with SR as the Village Apparatus of Gondang Legi District of Ambal stated the following:

"I believe that the program implementation is entirely accountable. The program charges no fees for poor people and students."

It can be seen that the free public transportation program has been conducted in an accountable manner because the community was not charged for using the transportation.

\section{Free public transportation expediency}

Expediency is interpreted as the program's impact on the community and how it positively contributes to people's welfare and its improvement (Sutherland et al. 2011). The main expedience measured in this study is the savings in terms of people's expenditure. The survey results show that the transportation expenditure savings reached $11.6 \%$ or $5,300-7,000$ IDR per day among the students while among the poor housewives, they saved up to 13,900 IDR per day. Compared to the control group, the target groups of this program are able to make savings in reference to their transportation costs. To measure whether the variations in the transportation cost saving are caused 
by the program's interventions, the following data shows the effect of the free public transportation program on the savings made in terms of public transportation spending.

Based on Table 13, the linear regression analysis between variables $\mathrm{X}$ (the free public transportation program) and $Y$ (savings on public expenditures), it was found that the magnitude of the effect is low at 0.347 in a positive direction. The influence between $\mathrm{X}$ and $\mathrm{Y}$ is also significant at the 0.010 level. This is because it is still below the 0.05 level. Based on the regression analysis, it can be said that there is a positive and significant effect between the $\mathrm{X}$ and $\mathrm{Y}$ variables.

Table 11.

Delivery accuracy level of the free public transportation program according to the control group

\begin{tabular}{lcccc}
\hline \multirow{2}{*}{ Delivery aspect } & \multicolumn{4}{c}{ Accuracy level } \\
\cline { 2 - 5 } & VT & T & LT & NT \\
\hline Fleet feasibility & 8 & 43 & 44 & 3 \\
Operating hours propernes & 5 & 59 & 23 & 11
\end{tabular}

\section{Notes:}

VT: Very timely

T: Timely

LT: Less timely

NT: Not-timely; after the proper time

Source: Analysis of the primary data (2018)

Table 12.

Fees needed to obtain a free public transportation coupon according to the community

\begin{tabular}{lcccc}
\hline \multirow{2}{*}{ Fees } & \multicolumn{2}{c}{ Targeted group } & \multicolumn{2}{c}{ Control group } \\
\cline { 2 - 5 } & Amount & $\%$ & Amount & $\%$ \\
\hline No fees required & 93 & 95 & 77 & 79 \\
Rarely pay for fees & 3 & 3 & 5 & 5 \\
Sometimes pay for fees & 2 & 2 & 5 & 5 \\
Always pay for fees & - & - & 11 & 12 \\
\hline \multicolumn{1}{c}{ Total } & $\mathbf{9 8}$ & $\mathbf{1 0 0}$ & $\mathbf{9 8}$ & $\mathbf{1 0 0}$ \\
\hline \multicolumn{2}{c}{ Source: Analysis of the primary data (2018) }
\end{tabular}

Table 13.

Influence of the free public transportation program $(X)$ on public expenditure $(Y)(n=196)$

\begin{tabular}{|c|c|c|c|c|}
\hline Influ & $(r)$ & R Square $\left(\mathbf{R}^{2}\right)$ & Adjusted R Square & Sig \\
\hline$(X) \rightarrow(Y)$ & 0.347 & 0.121 & 0.116 & 0.010 \\
\hline
\end{tabular}

Furthermore, variable $X$ has a determination coefficient (R2) of 0.121 . This shows that variable $X$ contributed $12.1 \%$ to the $\mathrm{Y}$ variable, while the contribution of other variables outside of the studied variables was $87.9 \%$. This means that there are $87.9 \%$ contributions from other variables that determine the savings in public expenditure $(\mathrm{Y})$ outside of the free public transportation program variable. Meanwhile, the Adjusted $\mathrm{R}$ Square value of 0.116 indicates that variable $\mathrm{X}$ affects the $\mathrm{Y}$ variable by $11.6 \%$. That is, the free public transportation Program $(\mathrm{X})$ is only able to influence the savings on public expenditure up to $11.6 \%$.

\section{Initial Outcomes}

The initial outcomes are that the program benefits are directly received and felt by the program beneficiaries. Among the benefits of the free public transportation program in the primary outcome, the category is the ability of the recipient community to save on transportation costs. The savings in terms of transportation costs, respectively, for both the students and the poor group, listed in Table 14. 
The budget of the transportation cost subsidies for students is 3,500 IDR per coupon. Each student is given two coupons per day to go to school (round trip). Thus, it can be estimated that each student will save of 7,000 IDR per day. However, the findings in the field prove that the average savings related to the student transportation costs were 5,300 IDR per day. The students who can only save 3,500 IDR are those who do not fully use coupons to go to school. Some are adding transportation costs independently related to their needs outside of school. It is different for the students who can save on their transportation costs by 7,000 IDR per day because they use more than two coupons per day. It is because students use coupons more than once. The different transportation costs also make the amount of savings for poor students, on average, 5,300 IDR. The amount of savings for poor students can be seen from the amount of money used for transportation costs before the free public transportation program and after getting on the program.

Table 14.

Saving on transportation expenditures for students

\begin{tabular}{cc}
\hline Saving internal (IDR) & Amount \\
\hline $0-3500$ & 9 \\
$3500-7000$ & 60 \\
$>7000$ & 5 \\
\hline Sources: Analysis of the primary data (2018)
\end{tabular}

Table 15.

Savings on Transportation Expenditures by the Public

\begin{tabular}{cc}
\hline Saving internal (IDR) & Amount \\
\hline $0-7500$ & 1 \\
$7500-15000$ & 19 \\
$>15000$ & 4 \\
\hline Sources: Analysis of the primary data (2018)
\end{tabular}

The budget for transportation costs subsidies for the poor group is, on average, 7,500 IDR per coupon. Each poor community is given two coupons per day for their travel needs, which usually used to travel to the market (round trip). It can be assumed that each of them will experience transportation cost savings of around 15,000 IDR per day. However, the findings from the field show that the saving average in terms of transportation cost was 13,900 IDR per day. It is because some communities need to make more than one leg of a journey to reach their destination. For example, some people need to stop at several spots before they reach the market that is their final destination. In addition, the distance between the destination and transportation costs before the free public transportation program is directly proportional - the further away from the destination, the higher the costs incurred for transportation. By using free transportation, so long as they still use the transportation with the correct routes, they do not need to incur additional costs.

Sajogyo (1997) argues that the level of household welfare assessed according to the percentage equalization of household expenditure referring to the per capita rice consumption per year, hence it was equalized with the average rice price in the local area. The level of rice consumption for poor people in rural areas, according to Sajogyo's benchmark (1997), is $320 \mathrm{Kg} /$ year or $26.7 \mathrm{Kg} /$ month. It means that the people who consume more rice than this number can be classified as the group who live above the poverty line. Based on the results of the study, it appears that after the enactment of the free public transportation program in Kebumen, the average community can reduce their spending by up to $55,600 \mathrm{IDR}$ in one month, equivalent to the consumption of $4.6 \mathrm{Kg}$ of rice assuming a price of $12,000 \mathrm{IDR} / \mathrm{kg}$. It can be seen that the free public transportation program can contribute $17.22 \%$ to poverty alleviation, assessed using household rice consumption.

For poor students, the amount of savings that can be achieved in one month is 168,000 IDR with the assumption of the active school days each month totaling 24 days, where they use two coupons per 
day. We assume that the rice price of $12,000 \mathrm{IDR} / \mathrm{Kg}$ and that it is equivalent to $14 \mathrm{Kg}$ of rice. Based on the Badan Pusat Statistik (BPS) data in 2016, the food consumption expenditure contributed $52.9 \%$ of the total household expenditure of the residents in the Kebumen Regency.

Table 16.

Program usability when facilitating community mobilization needs

\begin{tabular}{lll}
\hline Answer & Amount & Percentage (\%) \\
\hline Highly facilitative & 46 & 47 \\
Facilitative & 47 & 48 \\
Less facilitative & 4 & 4 \\
Not facilitative & 1 & 1 \\
\hline \multicolumn{2}{c}{ Sources: Analysis of the primary data (2018) }
\end{tabular}

After the implementation of the free public transportation program, the community needs to mobilize, whether it is to school, to work or to the market. This is made easier because there is no need to think about transportation costs or fees. The direct benefit of the program was also felt by the transport drivers, namely in the form of an increased income. Almost all of the transportation drivers experienced an increase in income. On average, they received an increase of 189,000 IDR.

\section{Intermediate Outcomes}

The benefits in the intermediate outcome category are the outcomes that expected to evoke the "end outcomes' but are not the end outcomes themselves. In this study, we measured five intermediate outcome indicators, namely self-appearance improvement, increased family nutrition, increased housing eligibility, increased productive venture, and increased savings. The end outcome of the free public transportation program is to improve the welfare of the poor.

In general, program beneficiaries enjoy free public transportation. The benefits improve their welfare by increasing the fulfillment of the family's primary and secondary needs. Given the many forms of budget diversion, the majority of the community, as the program beneficiary, choose to distribute their expenditure to improve the nutritional status of their family. The overall impact also provides benefits for the program partners, such as the public transport drivers and the transportation service entrepreneurs. As the indirect use of the program, they receive benefits when serving the free public transportation coupon for the community. Consequently, they have to follow the terms of the free public transportation program from the government. In terms of the program benefits, the free public transportation program benefits the drivers that they can make savings from their income.

Table 17.

Intermediate outcomes of the free public transportation program in Kebumen for the program beneficiaries

\begin{tabular}{lllll}
\hline \multirow{2}{*}{ Expediency } & \multicolumn{4}{l}{ Assessment } \\
\cline { 2 - 5 } & HB & B & LB & NB \\
\hline Self-appearance improvement & 26 & 63 & 5 & 4 \\
Increased family nutrition & 19 & 73 & 4 & 2 \\
Increased housing eligibility & 13 & 59 & 13 & 13 \\
Increased productive venture & 10 & 44 & 28 & 16 \\
Increased savings & 29 & 59 & 5 & 5 \\
\hline
\end{tabular}

Notes:

HB: Highly beneficial

B: Beneficial

LB: Less beneficial

NB: Not beneficial

Sources: Analysis of the primary data (2018) 


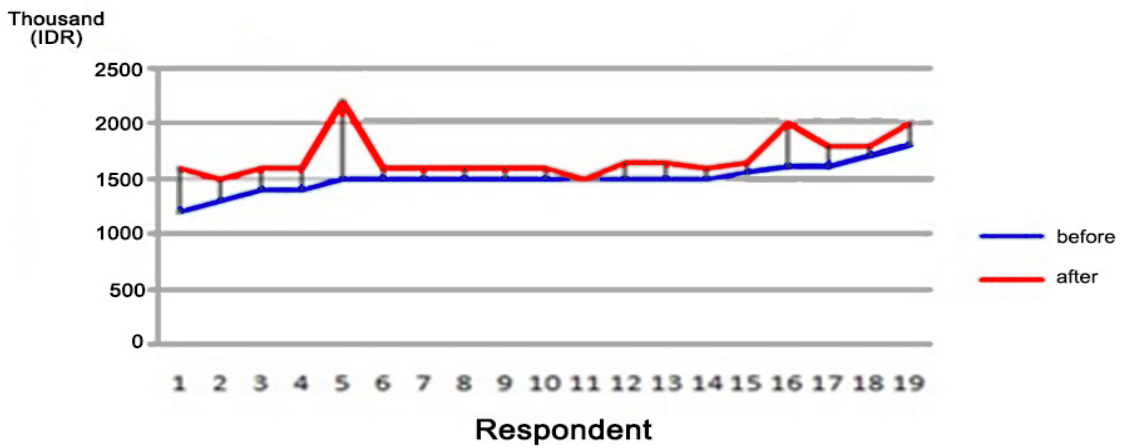

Figure 1.

Free public transportation driver income (before and after program)

Based on Table 18, it can be seen that $74 \%$ of transport drivers, after they incorporated into the free public transportation program, can put savings aside from their income. Furthermore, to measure the impact of the program, it is necessary to know the ability of the control community when increasing the fulfillment of the primary and secondary needs of the target group. In contrast to the target group, the control groups that do not receive the free public transportation program tend to have less of an ability to meet their primary and secondary needs because they do not have the same ability to make any savings in terms of their income.

Table 18.

Drivers' ability to save

\begin{tabular}{lcc}
\hline Saving ability & Amount & Percentage (\%) \\
\hline High & 1 & 5 \\
Sufficient & 14 & 74 \\
Low & 4 & 21 \\
Unable & 0 & 0 \\
Total & 19 & 100 \\
\hline \multicolumn{2}{l}{ Sources: Analysis of the primary data (2018) }
\end{tabular}

Table 19.

Intermediate outcome of the free public transportation Program in Kebumen regency for the control group

\begin{tabular}{lcccc}
\hline \multirow{2}{*}{ Expediency } & \multicolumn{4}{c}{ Assessment } \\
\cline { 2 - 5 } & HB & B & LB & NB \\
\hline Self-appearance improvement & 6 & 35 & 29 & 28 \\
Increased family nutrition & 2 & 46 & 26 & 24 \\
Increased housing eligibility & 9 & 27 & 28 & 34 \\
Increased productive venture & 1 & 29 & 25 & 43 \\
Increased savings & 4 & 32 & 40 & 22 \\
\hline
\end{tabular}

Notes:

HB: Highly beneficial

B: Beneficial

LB: Less beneficial

NB: Not beneficial

Sources: Analysis of the primary data (2018)

\section{Long-term outcomes}

The benefits received by the community as the program beneficiaries in terms of the long-term outcomes described in Figure 2. The community point of view is essential as they are the program beneficiaries in the long term outcome of the free public transportation program. Based on Figure 2, the free public transportation program is impactful in terms of reducing traffic congestion, increasing 
and mobilizing convenience, and increasing the enthusiasm of the community to go to work and or school. This program is also able to improve the students' learning achievements. However, through in-depth interviews with several stakeholders, the shortcomings remain that are causing the free public transportation program to be less effective. The problems are such as 1) route coverage, 2) social resistance, and 3) limited amount of buses in the fleet.

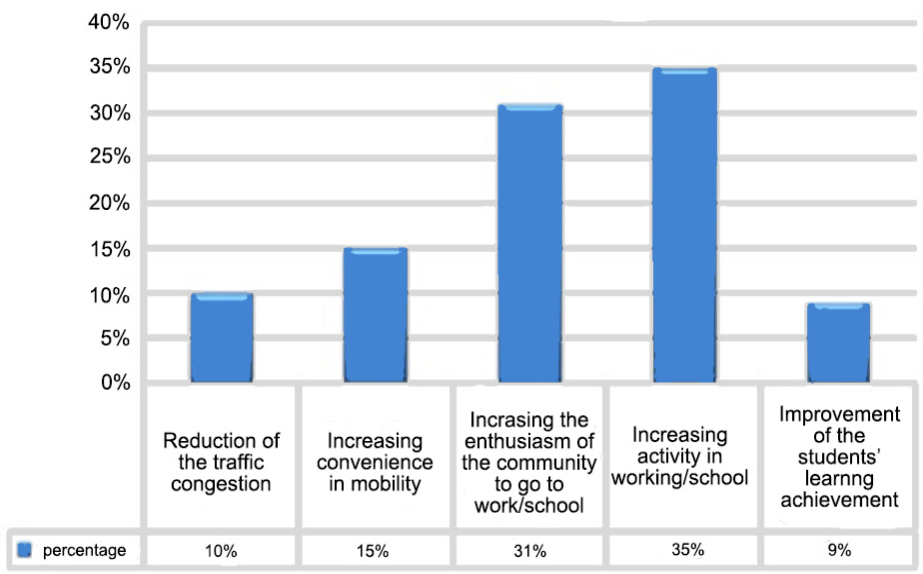

Figure 2.

Long-term outcomes of the program

\section{The problem of route coverage and problem of social resistance}

In the long run, a reassessment related to the effectiveness of the transportation routes in the domestic transportation system in Kebumen needed to create a transportation system that supports the activities of the Kebumen people more optimally. In the long term, it is necessary to change the image of the transportation subsidy program in order to minimize the impact of social resistance. The expansion of the target of transportation subsidies beyond the poor in society only is necessary.

\section{The problem of the limited amount of buses in the fleet}

In the long run, it is necessary to increase fleet because the problems related to fleet feasibility and the fleet's limited number remain significant. These reasons make some people unwilling to use free public transportation. The addition of extra buses to the fleet can provide convenience to make access to free public transportation faster. The results of the study showed that the free public transportation implementation program had a positive impact on both the target group and the non-target groups. The target groups who come from low-income families benefit by 1) improved access to public transportation to help them access education services and the market, 2) more savings when it comes to transportation, spending up to $11.6 \%$ or 3,000 IDR. It goes up to 7,000 IDR per day among students, while among homemakers, low-income families can save up to 13,900 IDR per day, and 3) It reduces the food expenditure, especially that of rice by $17.22 \%$ or 55,600 IDR per month.

Based on the analysis conducted, the free public transportation program is not only impactful when it comes to facilitating people's mobility. It also reduces the burden of transportation and food expenditure. These findings support the studies by Kidder (2006) and Litman (2017), which highlight the close relationship between access to transportation services in rural areas and poverty alleviation. As transportation needs to increase in rural areas, the spending on transportation services has also increased. The problem is, poverty is more common in rural areas. Subsidies of rural transportation services will help many low-income families to mobilize and save their income. With savings, transportation service subsidies can also have an impact on increasing the level of food consumption in low-income families.

This study also supports the findings of Porter (2002). The transportation system in rural areas can increase mobility and the poverty alleviation efforts undertaken. Our findings show that the free public transportation program can increase the enthusiasm of poor students when it comes to 
learning. It can be interpreted that the policy of providing public transportation facilities in rural areas can have positive social and economic impacts, especially for low-income families. Another impact due to the free public transportation services in Kebumen is the increase in the income of rural transport drivers. For them, free public transportation provides income certainty. Although the income is disbursed every month, the transport drivers report being able to make savings thanks to free public transportation services. This condition is good when it comes to maintaining public transport service activities in rural areas. The study conducted by Puspitasari (2018) also suggested that the mechanism of transportation service subsidies in rural areas had an impact on the sustainability of rural transportation operations. Another impact is that the mobility of students much supported by subsidized rural transportation. Thus the subsidized transport services have a broad positive impact on society.

\section{Conclusion}

Transportation service subsidies intended to ease the mobility of society and students from lowincome families. Local governments provide transportation service expenditure budgets each year to pay for these transportation services. Theoretically, these subsidies benefit the poor. Evaluation studies on the transportation service subsidy programs are needed to ascertain whether they benefit from the program.

In general, the process of implementing the free public transportation service program shows that both the program target group and the control group have easy access to meeting their transportation needs. Specifically, the target groups find it easy to get free public transportation service coupons. However, program coverage is not sufficient when it comes to reaching all low-income families. It is because some free public transportation routes do not reach several schools. In terms of the aspect of frequency, any bias, accuracy, and accountability can be fulfilled by the free public transportation service program will effort. Thus, this research concludes that the process of implementing the free public transportation service program is active. In terms of impact, an essential finding of this study shows that the free public transportation subsidy program in the short term has an impact on saving in terms of transportation spending among the poor. With these savings, the free public transportation program contributed $17.22 \%$ to poverty alleviation.

Other findings include the medium-term impact of the free public transportation service program that has improved self-appearance, family nutrition, housing eligibility, an increased number of productive ventures, and increased savings. Conversely, the control groups that do not utilize free public transportation services tend to be less able to meet either their primary or secondary needs. It is due to the inability of the control group to save when it comes to transportation spending. Another medium-term impact is that the free public transportation program increases the income of the transport drivers incorporated in the free public transportation service. Interestingly, the increase in income among the drivers, followed by the ability to save up.

The study also found that the long-term impact of free public transportation services has increased the learning enthusiasm among the students who receive the program to engage with work and study activities. With free public transportation services, traffic congestion, especially during working or school hours, has decreased. The free public transportation service program has generated a series of positive impacts, but some problems have also followed these. Some of the problems of the ineffective free public transportation service include the limited number of transportation routes, the possible social resistance, and the limited fleet availability. In its implementation, the route traveled by free public transportation services is limited to specific lines. As a result, not all students and community members from low-income families can enjoy free public transportation services.

The implication that proposed from the results of this study is there is a need to increase the route and extent of the free public transportation service coverage so then the access of the poor group in society to the transportation services also increases. Furthermore, the number of buses involved 
in the free public transportation services offered needs to be increased in order to provide greater mobility access from the community to carry out productive activities. Theoretically, research on evaluating the services of free public transportation should not be limited to its effects on the savings in terms of transportation costs. It also needs to be extended to other economic aspects such as access to the market and the local economy.

\section{References}

Aminah S (2006) Transportasi publik dan aksesibilitas masyarakat perkotaan Surabaya. Masyarakat, Kebudayaan dan Politik 20 (1):35-52.

Badan Pusat Statistik (2019) Presentase penduduk miskin Maret 2019 sebesar 9,41 persen. [Accessed 19 November 2019]. https://www.bps.go.id/pressrelease/2019/07/15/1629/persentase-pendu duk-miskin-maret-2019-sebesar-9-41-persen.html.

Badan Pusat Statistik (2017) Data informasi kemiskinan kabupaten/kota tahun 2017. [Accessed 27 April 2018]. https://www.bps.go.id/publication/2018/04/06/69f8e023485fcd4893164bbf/da ta-dan-informasi-kemiskinan-kabupaten--kota-tahun-2017.html.

Brinkerhoff DW \& Crosby BL (2002) Managing Policy Reform: Concepts and Tools for DecisionMakers in Developing and Transitioning Countries. Bloomfield, USA: Kumarian Press.

Bryceson DF, Bradbury A \& Bradbury T (2008) Roads to poverty reduction? Exploring rural roads impact on mobility in Africa and Asia. Development Policy Review 26 (4):459-482. https:// doi.org/10.1111/j.1467- 7679.2008.00418.x.

Dorosh P, Wang HG, You L \& Schmidt E (2012) Road connectivity, population, and crop production in Sub-Saharan Africa. Agricultural Economics 43 (1):89-103. https://doi.org/10.1111/j.15740862.2011.00567.x.

Finsterbusch K \& Motz AB (1980) Social Research for Policy Decisions. Belmont, California: Wadsworth Publishing Company.

Kebumen Ekspres (2017) Baru Saja Diluncurkan, Program Angkutan Gratis Sudah Dikeluhkan. [Accessed 2 September 2018]. http://www.kebumenekspres.com/2017/03/baru-saja-diluncur kan-program-angkutan.html.

Kidder B (2006) The Challenges of Rural Transportation. Published by the Western Rural Development Center. Printed in the United States of America.

Kompas (2018) Disparitas Kemiskinan Kota dengan Desa Tinggi. [Accessed 18 July 2018]. https:// eko nomi.kompas.com/read/2018/07/18/160637526/disparitas-kemiskinan-kota-dengandesa-tinggi-ini-penjelasan-kemenkeu.

Kurniawan R \& Yuniarto B (2017) Analisis Regresi: Dasar dan Penerapannya dengan R. Jakarta: Prenada Media.

Litman T (2017) Evaluating transportation diversity: Multimodal planning for efficient and equitable communities. [Accessed 18 July 2018]. Victoria Transport Policy Institute at www.vtpi.org/ choice.pdf.

Lucas K, Mattioli G \& Verlinghieri E (2016) Transport poverty and its adverse social consequences. Proceedings of the Institution of Civil Engineers - Transport. 169 (6):353-365. https://doi. org/10.1680/jtran.15.00073.

Madjid A, Masinambow V \& Wauran P (2015) Pengaruh program nasional pemberdayaan masyarakat (PNPM) mandiri perkotaan terhadap tingkat kemiskinan di Kota Kotamobagu. Jurnal Berkala Ilmiah Efisiensi 15 (4):113-123.

Porter G (2002) Improving mobility and access for the off-road rural poor through intermediate means of transport. World Transport Policy and Practise 8 (4):6-9.

Purwanto AE \& Sulistyastuti DR (2015) Implementasi Kebijakan Publik (Konsep dan Aplikasinya di Indonesia). Yogyakarta: Gava Media. 
Putra EP, Purnamadewi Y \& Sahara S (2015) Dampak program bantuan sosial terhadap pertumbuhan ekonomi dan kemiskinan kabupaten tertinggal di Indonesia. TATALOKA 17 (3):161-171. https://dx.doi.org/10.14710/tataloka.17.3.161-171.

Puspitasari R (2018) Analisis subsidi angkutan umum perdesaan bagi pelajar di Kabupaten Pasuruan. Jurnal Penelitian Transportasi Darat 20 (2): 93-106. https://doi.org/10.25104/jptd.v20i2.918.

Sajogyo T (1997) Garis Kemiskinan dan Kebutuhan Minimum Pangan. LPSBIPB. Bogor.

Suara Merdeka (2017) Anggaran Angkutan Gratis Habis. [Accessed 2 September 2018]. https:// www.suaramerdeka.com/smcetak/baca/45225/anggaran-angkutan-gratis-habis.

Sutherland WJ, Goulson D, Potts SG \& Dicks LV (2011) Quantifying the impact and relevance of scientific research. Plos One 6 (11):1-10. https://doi.org/10.1371/journal.pone.0027537.

Velaga NR, Beecroft M, Nelson JD, Corsar D \& Edwards P (2012) Transport poverty meets the digital divide: Accessibility and connectivity in rural communities. Journal of Transport Geography 21:102-112. https://doi.org/10.1016/j.jtrangeo.2011.12.005.

Wibawa S, Prabuningrat Y \& Pramusinto A(1994) Evaluasi Kebijakan Publik. Jakarta: Raja Grafindo Persada.

Winarno B (2008) Kebijakan Publik: Teori \& Proses. Yogyakarta: Media Pressindo. 